\title{
Management and retrospective analysis of primary and metastatic sacral tumors and infections: evaluation with 73 cases
}

\author{
Primer ve metastatik sakral tümör ve enfeksiyonların tedavisi ve retrospektif analizi: \\ 73 olgu ile değerlendirme
}

\author{
Murat Arıkan, MD., ${ }^{1}$ Güray Togral, MD., ${ }^{1}$ Aşkın Esen Hastürk, MD., ${ }^{2}$ Erdem Aktaş, MD., ${ }^{1}$ Şafak Güngör, MD. \\ 'Department of Orthopedics and Traumatology, Oncology Training and Research Hospital, Ankara, Turkey \\ ${ }^{2}$ Department of Neurosurgery, Oncology Training and Research Hospital, Ankara, Turkey
}

\begin{abstract}
Objectives: This study aims to evaluate the clinicopathologic characteristics and treatment modalities of 73 patients with benign and malign sacral tumors and infections from a single institution.

Patients and methods: Seventy-three patients (42 males, 31 females; mean age 48.9 years), who were treated between July 1991 and December 2013, with benign, malign tumors, and infections of the sacrum were retrospectively analyzed for a mean follow-up period of 25.4 months, and a review of the literature was conducted. While 36 patients were treated surgically, 37 were treated medically. Fifty-four patients were diagnosed with malign, and 19 with benign or infectious tumors.
\end{abstract}

Results: In 54 patients with malign tumors, metastasis was the most common diagnosis in 20 patients followed by chordoma in 11 , and multiple myeloma in 10 patients. Common benign lesions were osteomyelitis in four patients, and giant cell tumor and schwannoma in three patients each. Local recurrence was most commonly observed in the chordoma and chondrosarcoma groups with a rate of $50 \%$. Seven patients including five with metastatic disease, one with chondrosarcoma, and one with chordoma died during follow-ups. While urinary and anal incontinence developed in seven patients after sacral resection, deep infection was reported in four, and superficial infection was reported in two patients.

Conclusion: Because of the high complication rates in malign sacral tumors, we should perform wide resections with partial or total sacrectomy. Chordoma and chondrosarcoma patients should be screened closely due to a possible recurrence risk after sacrectomy while preserving the nerve roots as possible. Aggressive curettage should be combined with adjuvant methods in benign lesions due to high recurrence rates in sacral localization.

Keywords: Curettage; osteomyelitis; retrospective studies; sacrum.
Amaç: Bu çalışmada benign ve malign sakrum tümörleri ve enfeksiyonları olan, tek merkezden 73 olgunun klinikopatolojik özellikleri ve tedavi yöntemleri değerlendirildi.

Hastalar ve yöntemler: Temmuz 1991 - Aralık 2013 tarihleri arasında tedavi edilen ve sakral bölgede benign, malign tümörü ve enfeksiyonu olan 73 hasta (42 erkek, 31 kadın; ort. yaş 48.9 yıl) 25.4 ay ortalama takip süresi ile geriye dönük olarak incelendi ve literatür incelemesi yapıldı. Otuz altı hasta cerrahi yöntemle tedavi edilirken 37 hasta medikal yöntemle tedavi edildi. Elli dört hastaya malign, 19 hastaya benign veya enfeksiyöz tümör tanısı konuldu.

Bulgular: Malign tümörlü 54 hastada 20 hasta ile metastaz en yayg 1 tanı iken, bunu 11 hasta ile kordoma ve 10 hasta ile multipl miyeloma takip etti. Yaygın benign lezyonlar dört hastada osteomiyelit ve üçer hastada dev hücreli tümör ve schwannoma idi. Lokal nüks \%50'lik oran ile en sık kordoma ve kondrosarkoma grubunda görüldü. Beş metastatik hastalıklı, bir kondrosarkomlu ve bir kordomalı olmak üzere yedi hasta takiplerde kaybedildi. Sakral rezeksiyon sonrası yedi hastada üriner ve anal inkontinans gelişirken, dört hastada derin ve iki hastada yüzeyel enfeksiyon bildirildi.

Sonuç: Malign sakral tümörlerde yüksek komplikasyon oranları nedeniyle parsiyel veya total sakrektomi ile geniş rezeksiyonlar uygulamalıyız. Sakrektomi sonrası olası bir nüks riskine karşı kordoma ve kondrosarkoma hastaları yakından incelenmeli ve bu sırada sinir kökleri mümkün olduğunca korunmalıdır. Sakral lokalizayonda yüksek nüks oranları nedeniyle benign tümörlerde agresif küretaj ile adjuvan yöntemler birleştirilmelidir.

Anahtar sözcükler: Küretaj; osteomiyelit; retrospektif çalışmalar; sakrum.

- Received: September 08, 2014 Accepted: October 27, 2014

- Correspondence: Murat Arıkan, M.D. Ankara Onkoloji Eğitim ve Araştırma Hastanesi Ortopedi ve Travmatoloji Kliniği, 06200 Demetevler, Ankara, Turkey. Tel: +90 312 - 3360909 Fax: +90 312 - 3340352 e-mail: smuratark@yahoo.com 
Sacral and presacral tumors are extremely rare and may arise from a neoplastic nidus in bone, cartilage, or soft tissue. ${ }^{[1]}$ Their incidence among all bone tumors varies between $1 \%$ and $4.3 \% .^{[2]}$ The most common benign aggressive tumors of sacrum are; giant cell tumor (GCT), aneurysmal bone cyst (ABC) and osteoblastoma. ${ }^{[1]}$ Among these, GCT is the most common and accounts for nearly half of benign sacral tumors. While en bloc resection is the gold standard treatment choice in sacral GCT, adjuvant treatments like intracavitary cryotherapy or thermo cauterization followed by intralesional excision is an alternative treatment modality although it is associated with a high recurrence rate. ${ }^{[3]}$

The accepted treatment for sacral aneurysmal bone cysts and osteoblastoma is aggressive curettage followed by local adjuvant treatments and bone grafting. ${ }^{[4]}$ Most common primer malignant tumors located in sacrum are low-grade malignancies like chordoma or chondrosarcoma. ${ }^{[1,2]}$ En bloc resection with functional reconstruction in cases where the lesion is high in the sacrum has been demonstrated to increase the disease-free survival period unresponsive to chemotherapy and radiotherapy. ${ }^{[3]}$ Primary high-grade malignant tumors, including osteosarcoma, chondrosarcoma, and Ewing sarcoma (ES) are extremely rare in the sacrum, and intralesional resection without adequate margins may lead to high local recurrence rates. ${ }^{[5]}$ Metastases are in fact the most common malignant tumors of the sacrum with poor survival rates. ${ }^{[6]}$ The most important predictor of local recurrence and survival for most common primary malign tumors (chordomas and chondrosarcomas) is a negative surgical margin. ${ }^{[7]}$

Sacral bone infections are very rare manifestations of either hematogenous spread of an infection in the body or complication of an intra-abdominal operation. Surgical debridement combined with antibiotics is usually necessary for complete cure.

Sacral tumors have high intraoperative and postoperative complications including neurological compromise, infection, vascular injuries, abdominal organ injuries and soft tissue defects leading to high mortality and morbidity rates. ${ }^{[8]}$ In this study, we aimed to evaluate the clinicopathologic characteristics and treatment modalities of 73 patients with benign and malign sacral tumors and infections from a single institution.

\section{PATIENTS AND METHODS}

This study reviews the clinical data of 73 patients (42 males, 31 females; mean age 48.9 years) with primary and metastatic sacral tumors, benign lesions and infections treated surgically or conservatively, and the analysis of the long-term clinical results with complications of patients undergoing en bloc resection in Ankara Oncology Training and Research Hospital between July 1991 and December 2013. Patients were followed up for a mean period of 26.3 months (range 1-194 months). Major complaints of the patients were pain, neurological deficit, walking disability, paresthesia, weakness, bowel and/or bladder dysfunction. The duration of preoperative symptoms ranged between 1-36 months. Fifty-four patients $(73.9 \%)$ had malign lesions (Figure 1), and 19 patients (26.1\%) had either benign lesions or infections (Figure 2). Histopathologic diagnosis was confirmed with fine needle aspiration biopsy in 47 patients (64.38\%) and open incisional biopsy in 26 patients. Of the 73 patients; 36 were treated surgically (49\%) and 37 only had biopsy and non surgical treatment modalities. Surgical planning was decided according to the localization, extent and histopathology of the lesion. Curettage was applied to five patients, curettage and thermo- or chemocauterization and autogenous iliac bone grafting were performed in three patients, curettage and thermo- or chemocauterization and polymethylmetacrylate (PMMA) were performed in two patients, curettage and thermo- or chemocauterization and posterior instrumentation were performed in one patient, subtotal sacrectomy was performed in 21 patients, partial sacrectomy and reconstruction with PMMA were performed in two patients, partial sacrectomy and reconstruction with fresh frozen fibula and lumbopelvic stabilization were performed in one patient, total sacrectomy and lumbopelvic stabilization were performed in one patient (Figure 3).

Single stage posterior approach was performed in 15 patients treated with partial sacrectomy and combined anterior-posterior approach was preferred

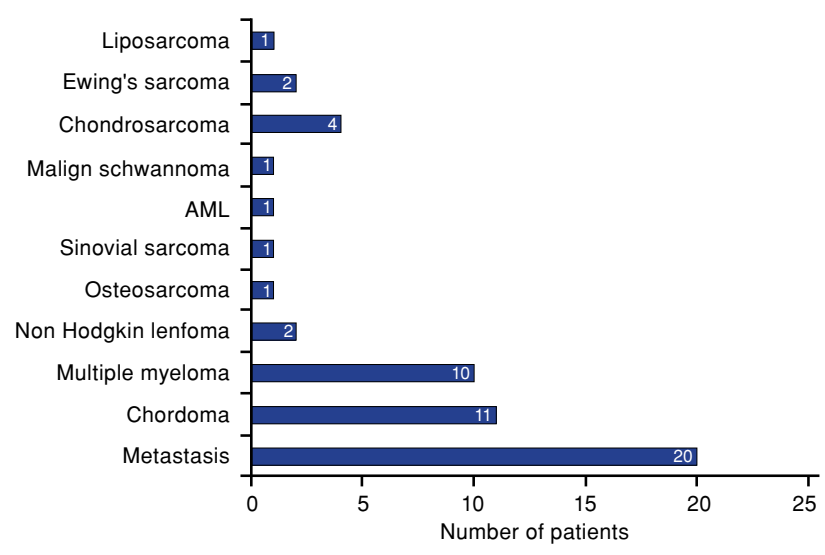

Figure 1. Diagram showing the histopathologic distribution of 54 malign tumors located in sacrum. AML: Acute myeloid leukemia. 


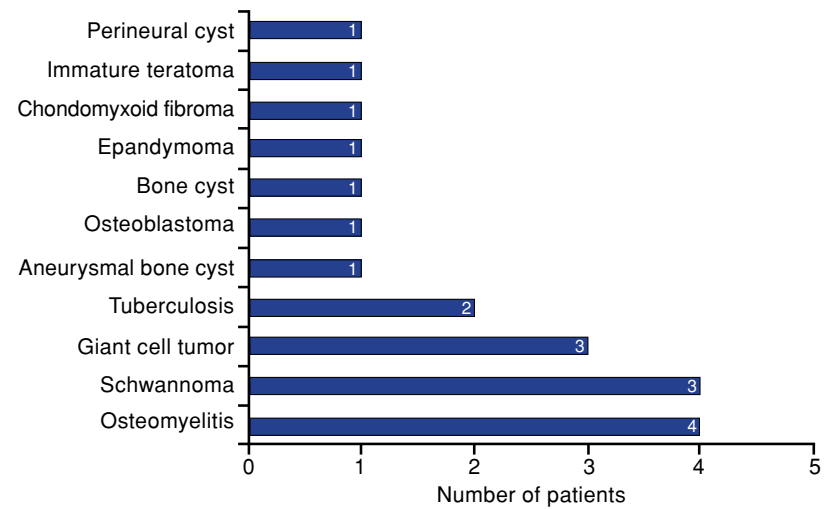

Figure 2. Diagram showing the histopathologic distribution of 19 benign tumors or infections located in the sacrum.

in five patients; four in chordoma cases for partial resection above S3 level and one in ependymoma at S1 level extending through spinal canal. Colostomy was necessary in five patients treated with a combined procedure.

\section{RESULTS}

In our series, 10 patients with chordoma were treated surgically with partial sacrectomy (Figure 4) and one patient was inoperable and received only radiotherapy. Surgical margins were wide in six and wide contaminated in four patients, and local recurrence developed in five patients $(50 \%)$. One superficial wound infection and one deep wound infection were noted in the follow-up period. Aggressive curettage and bone cementation were performed in one and subtotal sacrectomy was performed in three patients with giant chondrosarcoma. Partial hemisacrectomy was performed in a 27-year-old female for grade 2 chondrosarcoma (Figure 5). The surgical margins were wide in two patients and wide contaminated in two patients with chondrosarcoma. Local recurrence was recorded in two patients (50\%) with near surgical margins. Two patients experienced permanent and anal incontinence after sacrectomy and one patient developed deep wound infection.

Three patients with GCT were treated surgically; two with partial sacrectomy and one was treated with aggressive curettage and posterior instrumentation with bone cement application (Figure 6). Local recurrence developed in the patient treated with curettage and posterior instrumentation, and the patient was treated with partial sacrectomy. Three patients with benign schwannoma were treated with partial sacrectomy. Local recurrence developed in two of the patients. Total sacrectomy and reconstruction with fibular allograft and lumbopelvic stabilization

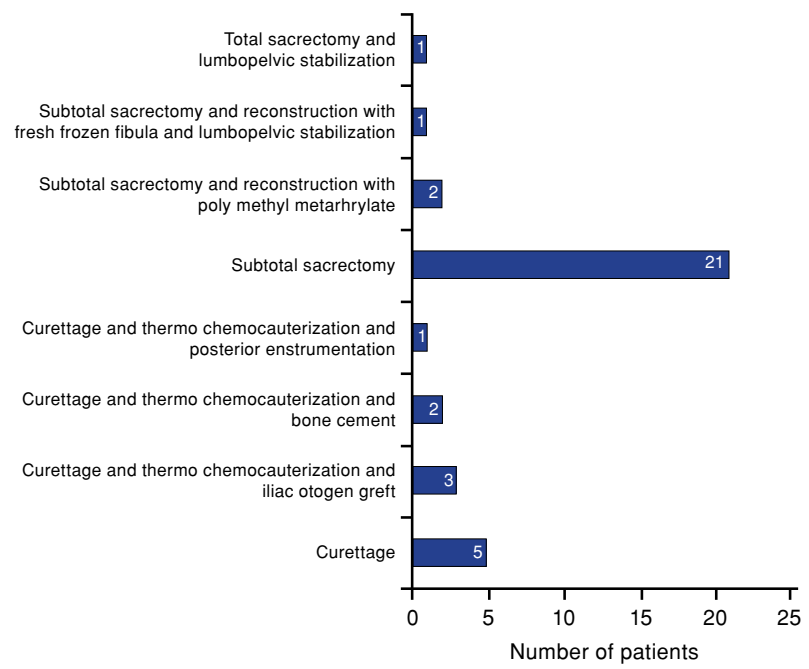

Figure 3. Table showing the distribution of methods of surgical interventions for sacrum tumors in 36 patients.

were performed to one of these patients revealing a 16 months disease free follow-up. The other patient with local recurrence underwent partial sacrectomy at the upper level and is still with no evidence of disease. Partial sacrectomy was performed to the patient with malignant schwannoma but local recurrence was reported at the eighth month followup, and the patient was later treated with sequential resection.

The surgical margins were wide in patients with liposarcoma and synovial sarcoma without any recurrence at six and seven months follow-up, respectively. Two patients with Ewing's sarcoma were inoperable and one of these patients was a 17-year-old female patient with sarcoma located at S2-4 level with extensive soft tissue invasion (Figure 7). Although the patient diagnosed with osteosarcoma was inoperable, partial sacrectomy was performed to the patient with yolk sac tumor with clear margins and is free of disease at the $12^{\text {th }}$ month follow-up. Major complications after sacral resections were urinary and anal incontinence in seven patients, deep wound infections requiring serial debridement and parenteral antibiotics in four patients, lower extremity motor deficit in two patients, dropped foot in one patient, major intraoperative bleeding in two patients, and superficial infection in two patients. Most common neurologic dysfunctions observed in chordoma patients was urinary and anal incontinence in five patients. We recorded postoperative urinary and anal incontinence in two patients with permanent impotence and in one patient after sacral resection for chondrosarcoma. Patient with ependymoma demonstrated permanent anal and urinary incontinence and major intraoperative 

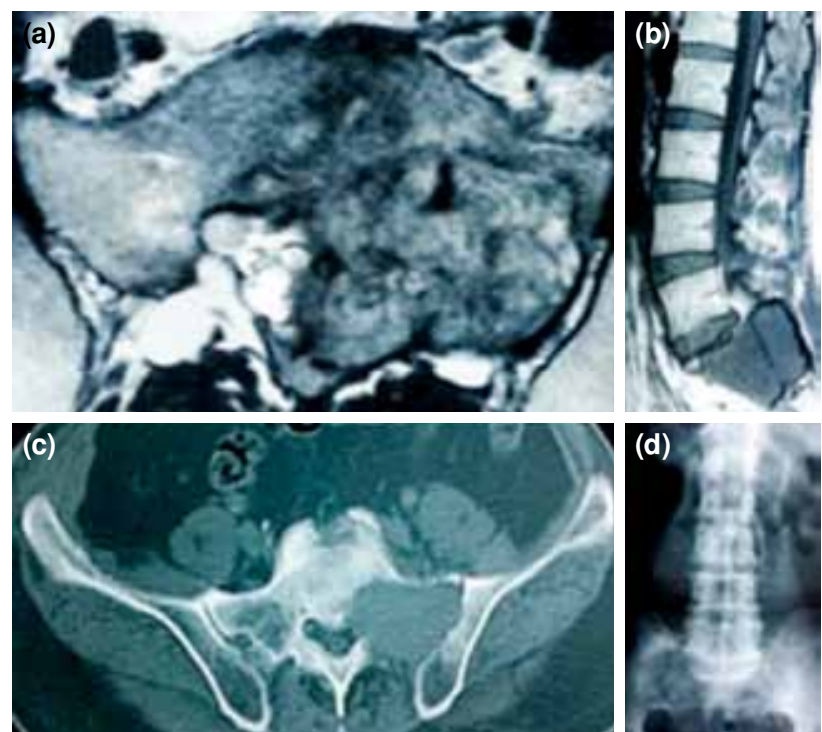

Figure 4. (a, b) Axial and sagittal magnetic resonance imaging sequences showing a destructive, heterogenous bone lesion at the left side of $S 1$ with soft tissue involvement with a diagnosis of chordoma. (c, d) Axial computed tomography and anteroposterior X-ray of a metastatic carcinoma of thyroid at S2-3 level invading through sacroiliac joint.

bleeding after total sacrectomy and lumbopelvic reconstruction.

\section{DISCUSSION}

Sacral tumors are very rare and can easily be confused with lumbar or pelvic tumors because of the anatomical structure of the pelvis. ${ }^{[8,9]}$ Sacral metastases are considered to be the most common tumors (Figure 4) at this localization, which is compatible with a study comprising $41 \%$ of all cases. ${ }^{[1]}$ Similarly, in our series, metastatic lesions were the most common with $28 \%$. Intractable pain and mechanical instability due to lumbopelvic junction structural failure are the main indications for surgical intervention with modified Galveston technique in metastatic involvement of sacrum. ${ }^{[9-11]}$ In our study, among 20 patients, only one patient with rectal carcinoma metastasis was treated with sacrectomy.

Sacral chordomas have high postoperative morbidity rates after intralesional resections. Although no local recurrence was recorded in our patients with wide surgical margins, local recurrence developed in four patients with wide contaminated margins. Bergh et al. ${ }^{[12]}$ reported that patients treated with wide surgical excision had a recurrence rate of $17 \%$, while in patients treated with intralesional or marginal resection, the recurrence rate was $81 \%$. This data was consistent with our findings. Although metastasis rates are known to be $5-70 \%$
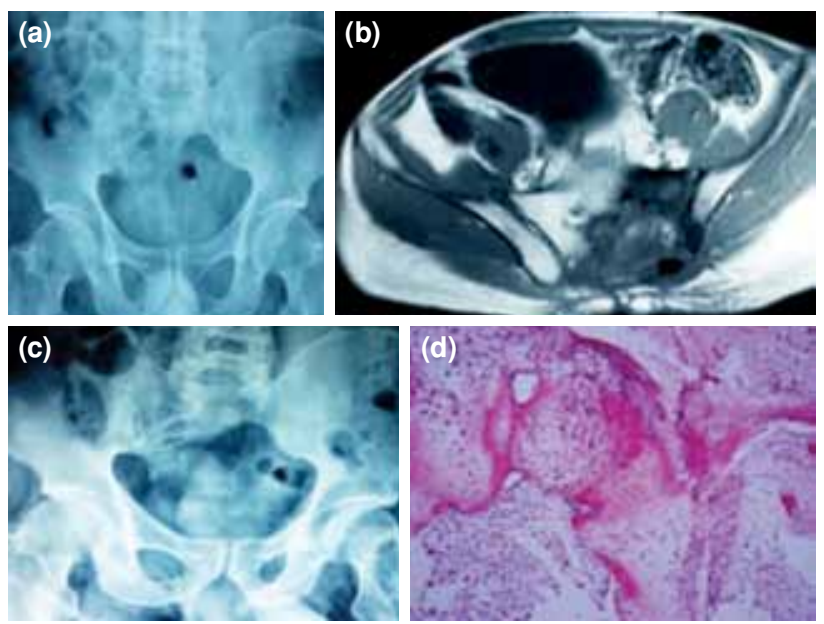

Figure 5. (a) Anteroposterior $X$-ray of a grade 2 chondrosarcoma in the left side of S3-4 localization. (b) Axial $\mathrm{T}_{1}$ magnetic resonance imaging sequence showing the destructive lesion at the left side of S3-4 crossing the midline. (c) Postoperative anteroposterior X-ray after partial sacrectomy. (d) H-E x 100 magnification revealing chondrocytes with increased nuclear to cytoplasmic ratios, irregular nuclear membrane and nucleoli.

in the literature with chordomas, ${ }^{[12,13]}$ no metastasis was recorded in our series of 11 patients. Among 10 surgically treated patients, we recorded three transient and two permanent sphincter deficits, one dropped foot and one motor deficit at the lower extremity. These patients all had tumors above the critical S3-4 level.

Sacral giant cell tumors are the most common benign tumors of the sacrum and most of these are Campanacci grade 3 tumors with invasive growth. ${ }^{[14]}$ In our series, three patients were operated with sacral GCT. Partial sacrectomy with wide margins in two patients and intralesional curettage with posterior implantation with bone grafting in one patient were performed. We experienced local recurrence only in the patient treated with intralesional curettage.

Sacral schwannomas are very rare and are seen in less than $1 \%$ to $5 \%$ of all spinal schwannomas. ${ }^{[15]}$ In our series, the percentage of sacral schwannomas is compatible with the literature accounting to $4.1 \%$ of all cases. One of our cases treated with partial sacrectomy developed local recurrence four months after the surgery. According to Cagli et al., ${ }^{[16]}$ only 50 giant sacral schwannomas have been reported in the literature.

The incidence of sacral chondrosarcoma is very low. Unni et al. reported that only 18 cases of chondrosarcoma were observed out of 900 tumor cases $(0.2 \%) \cdot{ }^{[17]}$ We reported four patients $(5.4 \%)$ in our series which is much higher than the rate in mentioned 

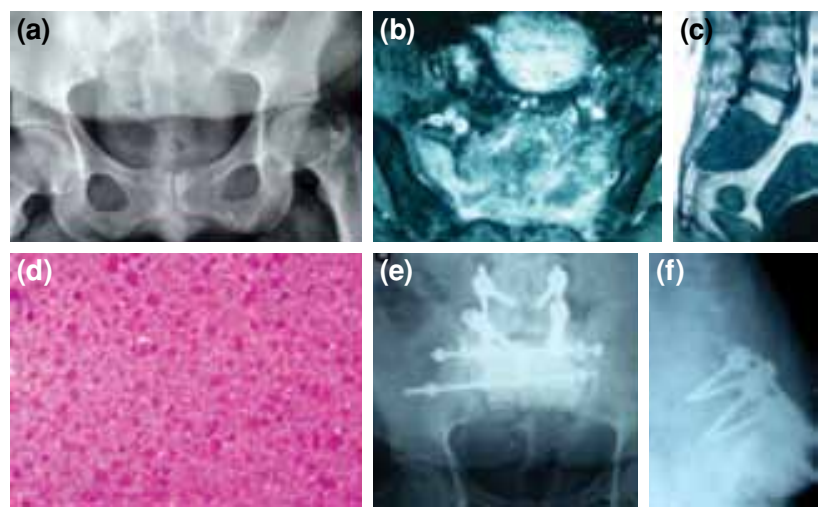

Figure 6. (a) Anteroposterior X-ray of a 39-year-old woman with giant cell tumor at $\mathrm{S} 1-3$ level. $(\mathbf{b}, \mathbf{c})$ Axial $\mathrm{T}_{2}$ and sagittal $\mathrm{T}_{1}$ magnetic resonance imaging sequences revealing the heterogeneous mass involving both sides of S1-2 invading sacroiliac joint. (d) Microscopically, stromal cells have poorly defined cytoplasm borders and bland nuclei resembling those of giant cells in $\mathrm{H}-\mathrm{E} \times 200$ magnification. $(\mathbf{e}, \mathbf{f})$ Postoperative anteroposterior and lateral $\mathrm{X}$-rays showing aggressive curettage and replenishment of the cavity with polymethyl metacrylate. Lumbopelvic stabilization with rods and screws is performed in order to augment the stability.

literature. Histopathologic examination was consistent with peripheral secondary chondrosarcoma in three young patients and central chondrosarcoma in a 54-year-old patient. Our recurrence rate was $50 \%$, which can be accepted as high. The prognosis of sacral chondrosarcoma is closely related to the adequacy of surgical margins and histological grade of the tumor. Recurrence rates are as low as $20 \%$ after successful en bloc excision. Aneurysmal bone cysts are very rare entities, accounting for less than $4 \%$ of all reported cases, and aggressive surgical curettage with adjuvant therapies are still considered as the standard treatment. ${ }^{[18-20]}$ No major bleeding or local recurrence was reported in our patient with $A B C$, and 84 months follow-up revealed no complication. Multiple myeloma is the second most common primary malignant neoplasm of the sacrum after chordoma. In our series, myelomas were present in the sacral region in 10 patients $(13 \%)$. This high percentage is similar with the series of Guo et al. ${ }^{[21]}$ Only one patient was surgically treated with partial sacrectomy without any complication at the $28^{\text {th }}$ month of follow-up. Sacral osteomyelitis are extremely rare manifestations of hematogenous spread of a primary infection in the body or complication of an intraabdominal operation like ileal pouch-anal anastomosis or assisted abdominal sacral colpopexy. ${ }^{[22,23]}$ We report four cases of sacral osteomyelitis; two patients after abdominal sacral colpopexy operation, and two patients during the course of disseminated infection
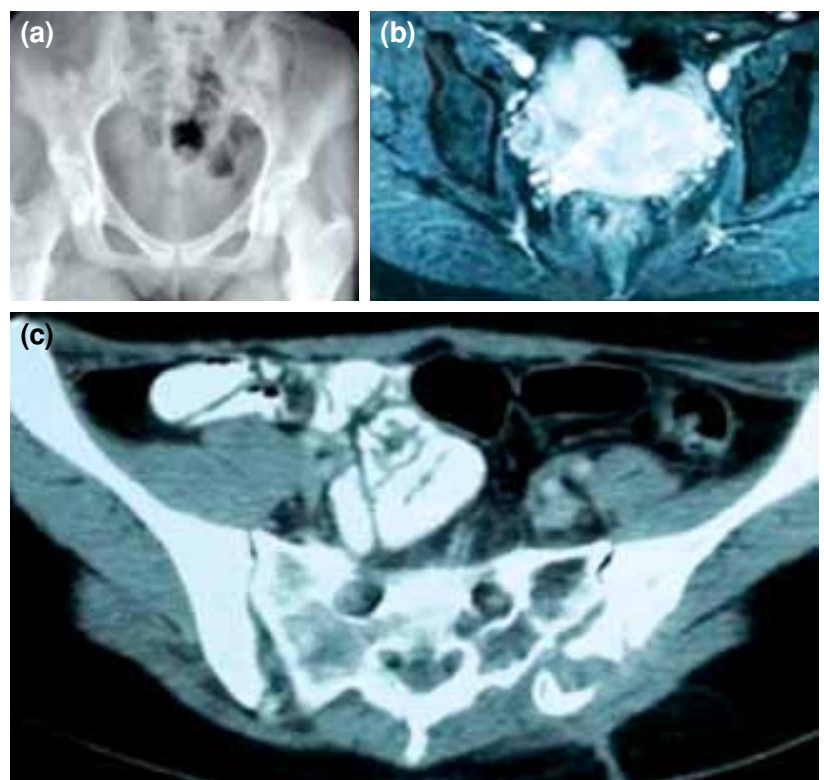

Figure 7. (a) Anteroposterior X-ray of a 17-year-old female patient with Ewing sarcoma located at S2-4 level showing destruction of the bone. (b) $\mathrm{T}_{2}$ weighted axial magnetic resonance imaging section showing the destruction of the right sacral ala and extensive soft tissue involvement. (c) Axial computed tomography image showing the bony destruction at the right side of the sacrum. The patient received chemo and radiotherapy as the lesion was inoperable.

in the body. All of the patients were treated with curettage of the lesion combined with parenteral antibiotics. No complications were recorded in the postoperative period, and all of the four patients have no evidence of disease with a mean follow-up period of 54 months. Isolated sacral tuberculosis is extremely rare. ${ }^{[2]}$ Diagnosis has to be confirmed by a positive culture from the aspirated material. ${ }^{[25,26]}$ We report a 44-year-old female patient with nonspecific low back pain symptoms who was treated with anti-tuberculosis medication successfully. Sacral ependymomas are very rare tumors, commonly associated with conus medullaris and cauda equina. After resection of this tumor, pelvic instability due to discontinuity between the spine and pelvis must be stabilized by lumbopelvic reconstruction with rods and screws. ${ }^{[27,28]}$ A 32-year-old female patient was presented with the diagnosis of ependymoma at S1-3 localization. Following wide resection, permanent urinary and anal incontinence were observed. Chondromyxoid fibromas (CMF) are very rare in the lumbosacral area with vertebral origin representing about 5\%. ${ }^{[29]}$ Current management of CMF in the sacral area includes removal of the tumor with total en bloc resection or curettage. ${ }^{[30]}$ We report a 48 -year-old male patient with CMF in S1-3 localization, treated with aggressive curettage and autogenous iliac bone 
grafting. Leptomeningeal infiltration is a common complication of acute leukemia; however, involvement of nerve roots, plexus or peripheral nerves is rare. ${ }^{[3]}$ In our series, a 30-year-old male patient with the diagnosis of acute promyelocytic leukemia was treated with chemotherapy and is in remission. Primary sacral lymphomas of the sacrum are the third common primary malign tumors of the sacrum after chordoma. ${ }^{[32]}$ Sacrococcygeal teratoma is a rare tumor. In a recent study, Yoneda et al. ${ }^{[33]}$ reported that mature teratomas were the most common diagnosed type followed by immature types. We present a one-year-old girl with sacrococygeal teratoma at S4-C3 level treated with partial sacrectomy. Ewing sarcoma has the worst prognosis when they occur in the sacrococcygeal region with local control being accomplished in only $62.5 \%$ cases, and having longterm survival of only $25 \% .{ }^{[34]}$ The primary treatment modality in this localization is chemotherapy and radiotherapy, but in some instances surgery may be required for decompression and stabilization. Here, we report three patients with ES; two primary, one metastatic. We report a patient with irresectable sacral osteosarcoma in the fourth decade of life. ${ }^{[35]}$

Wide surgical resection is the gold standard treatment for localized primary malignant sacral tumors except hematologic malignancies. Near surgical margins should be avoided since recurrence rates are as high as 50\%. S2 is the critical level for sacrectomy. Urinary and anal incontinence rates are high $(35.6 \%)$ above this level. If possible, wide resection should be performed through the vertebral body cephalad to the uppermost diseased level below S2. Damage at S4-S5 nerves are not known to be associated with any significant urinary or bowel problems. ${ }^{[3,37]}$ Particularly in chordoma and chondrosarcoma patients undergoing surgical intervention, preventive measures must be taken for superficial and deep wound infections since these are very common complications. Different from malign tumors, aggressive curettage with local neoadjuvant can offer the best results in benign tumors. For all sacral region infections, we advocate thorough debridement combined with parenteral antibiotics.

\section{Declaration of conflicting interests}

The authors declared no conflicts of interest with respect to the authorship and/or publication of this article.

\section{Funding}

The authors received no financial support for the research and/or authorship of this article.

\section{REFERENCES}

1. Syed R, Bishop JA, Ali SZ. Sacral and presacral lesions: cytopathologic analysis and clinical correlates. Diagn Cytopathol 2012;40:7-13.

2. Sar C, Eralp L. Surgical treatment of primary tumors of the sacrum. Arch Orthop Trauma Surg 2002;122:148-55.

3. Shen CC, Li H, Shi ZL, Tao HM, Yang ZM. Current treatment of sacral giant cell tumour of bone: a review. J Int Med Res 2012;40:415-25.

4. Ayan I, Serinsöz E. Osteoblastoma in the os hamatum: a rare case report. [Article in Turkish] Eklem Hastalik Cerrahisi 2014;25:56-.

5. Bederman SS, Shah KN, Hassan JM, Hoang BH, Kiester PD, Bhatia NN. Surgical techniques for spinopelvic reconstruction following total sacrectomy: a systematic review. Eur Spine J 2014;23:305-19.

6. Demirçay E, Civelek E, Demiralay E. Solitary spinous process metastasis: a case report. Eklem Hastalik Cerrahisi 2013;24:58-61.

7. Quraishi NA, Giannoulis KE, Edwards KL, Boszczyk BM. Management of metastatic sacral tumours. Eur Spine J 2012;21:1984-93.

8. Zhang ZY, Fu CF, Yang YX, Wang LQ, Cui Y, Liu Y. Long-term outcomes following en bloc resection for sacral tumor: a retrospective analysis of 93 cases. Orthopedics 2011;34:e403-7.

9. Cody HS 3rd, Marcove RC, Quan SH. Malignant retrorectal tumors: 28 years' experience at Memorial Sloan-Kettering Cancer Center. Dis Colon Rectum 1981;24:501-6.

10. Feiz-Erfan I, Fox BD, Nader R, Suki D, Chakrabarti I, Mendel E, et al. Surgical treatment of sacral metastases: indications and results. J Neurosurg Spine 2012;17:285-91.

11. Jackson RJ, Gokaslan ZL. Spinal-pelvic fixation in patients with lumbosacral neoplasms. J Neurosurg 2000;92(1 Suppl):61-70.

12. Bergh P, Kindblom LG, Gunterberg B, Remotti F, Ryd W, Meis-Kindblom JM. Prognostic factors in chordoma of the sacrum and mobile spine: a study of 39 patients. Cancer 2000;88:2122-34.

13. York JE, Kaczaraj A, Abi-Said D, Fuller GN, Skibber JM, Janjan NA, et al. Sacral chordoma: 40-year experience at a major cancer center. Neurosurgery 1999;44:74-9.

14. Guo W, Ji T, Tang X, Yang Y. Outcome of conservative surgery for giant cell tumor of the sacrum. Spine (Phila Pa 1976) 2009;34:1025-31.

15. Zhou M, Chen K, Wu C, Yang H. Giant sacral schwannoma with pelvic and lumbar spine extension. Spine J 2013;13:1154-5.

16. Çağlı S, Işık HS, Yıldırım U, Akıntürk N, Zileli M. Giant sacral schwannomas. J Neurooncol 2012;110:105-10.

17. Unni KK. Chondrosarcoma (primary, secondary, dedifferentiated and clear-cell). In: Dahlin's bone tumors. General aspects and data on 11,087 cases. 5th ed. Philadelphia: Lippincott-Raven; 1996. p. 71-108.

18. Donati D, Frisoni T, Dozza B, DeGroot H, Albisinni U, Giannini S. Advance in the treatment of aneurysmal bone cyst of the sacrum. Skeletal Radiol 2011;40:1461-6.

19. Gibbs CP Jr, Hefele MC, Peabody TD, Montag AG, Aithal $\mathrm{V}$, Simon MA. Aneurysmal bone cyst of the extremities. Factors related to local recurrence after curettage with a high-speed burr. J Bone Joint Surg [Am] 1999;81:1671-8. 
20. Peeters SP, Van der Geest IC, de Rooy JW, Veth RP, Schreuder HW. Aneurysmal bone cyst: the role of cryosurgery as local adjuvant treatment. J Surg Oncol 2009;100:719-24.

21. Guo W, Xu WP, Yang RL, Tang XD. The surgical management of sacral tumors. Zhonghua Wai Ke Za Zhi 2003;41:827-31. [Abstract]

22. Nosseir SB, Kim YH, Lind LR, Winkler HA. Sacral osteomyelitis after robotically assisted laparoscopic sacral colpopexy. Obstet Gynecol 2010;116 Suppl 2:513-5.

23. Muffly TM, Diwadkar GB, Paraiso MF. Lumbosacral osteomyelitis after robot-assisted total laparoscopic hysterectomy and sacral colpopexy. Int Urogynecol J 2010;21:1569-71.

24. Kumar A, Varshney MK, Trikha V. Unusual presentation of isolated sacral tuberculosis. Joint Bone Spine 2006;73:751-2.

25. Utkan A, Gülbahçe K, Ciliz A, Tümöz MA. Miliary tuberculosis presented as a sacroiliitis: a case report. [Article in Turkish] Eklem Hastalik Cerrahisi 2009;20:161-4.

26. Punia VPS, Kumar S. Atypical manifestation of sacral tuberculosis as Cauda-conus syndrome. JIACM 2000;9:57-6

27. Doita M, Harada T, Iguchi T, Sumi M, Sha H, Yoshiya S, et al. Total sacrectomy and reconstruction for sacral tumors. Spine (Phila Pa 1976) 2003;28:E296-301.

28. Choudry UH, Moran SL, Karacor Z. Functional reconstruction of the pelvic ring with simultaneous bilateral free fibular flaps following total sacral resection. Ann Plast Surg 2006;57:673-6.

29. Ahuja SK, McCanna SP, Horn EM. Treatment strategy for chondromyxoid fibroma of the sacrum. J Clin Neurosci 2011;18:1550-2.
30. Mehta S, Szklaruk J, Faria SC, Raymond AK, Whitman GJ. Radiologic-pathologic conferences of the University of Texas M. D. Anderson Cancer Center: Chondromyxoid fibroma of the sacrum and left iliac bone. AJR Am J Roentgenol 2006;186:467-9.

31. Kesari S, Drappatz J, Akar S, Vergilio JA, Wen PY, Soiffer RJ, et al. Recurrent acute promyelocytic leukemia presenting as a sacral nerve root mass. J Clin Oncol 2008;26:3279-81.

32. Ha AS, Chew FS. Imaging of sacral masses: self-assessment module. AJR Am J Roentgenol 2010;195(3 Suppl):S32-6.

33. Yoneda A, Usui N, Taguchi T, Kitano Y, Sago H, Kanamori $\mathrm{Y}$, et al. Impact of the histological type on the prognosis of patients with prenatally diagnosed sacrococcygeal teratomas: the results of a nationwide Japanese survey. Pediatr Surg Int 2013;29:1119-25.

34. Murphey MD, Andrews CL, Flemming DJ, Temple HT, Smith WS, Smirniotopoulos JG. From the archives of the AFIP. Primary tumors of the spine: radiologic pathologic correlation. Radiographics 1996;16:1131-58.

35. Thornton E, Krajewski KM, O’Regan KN, Giardino AA, Jagannathan JP, Ramaiya N. Imaging features of primary and secondary malignant tumours of the sacrum. Br J Radiol 2012;85:279-86.

36. Thornton E, Krajewski KM, O’Regan KN, Giardino AA, Jagannathan JP, Ramaiya N. Imaging features of primary and secondary malignant tumours of the sacrum. Br J Radiol 2012;85:279-86.

37. Puri A, Agarwal MG, Shah M, Srinivas CH, Shukla PJ, Shrikhande SV, et al. Decision making in primary sacral tumors. Spine J 2009;9:396-403. 